\title{
Growth hormone in the presence of laminin modulates interaction of human thymic epithelial cells and thymocytes in vitro
}

\author{
Marvin Paulo Lins, Larissa Fernanda de Araújo Vieira, Alfredo Aurélio Marinho Rosa and Salete Smaniotto*
}

\begin{abstract}
Background: Several evidences indicate that hormones and neuropeptides function as immunomodulators. Among these, growth hormone $(\mathrm{GH})$ is known to act on the thymic microenvironment, supporting its role in thymocyte differentiation. The aim of this study was to evaluate the effect of GH on human thymocytes and thymic epithelial cells (TEC) in the presence of laminin.

Results: GH increased thymocyte adhesion on BSA-coated and further on laminin-coated surfaces. The number of migrating cells in laminin-coated membrane was higher in GH-treated thymocyte group. In both results, VLA-6 expression on thymocytes was constant. Also, treatment with $\mathrm{GH}$ enhanced laminin production by TEC after $24 \mathrm{~h}$ in culture. However, VLA-6 integrin expression on TEC remained unchanged. Finally, TEC/thymocyte co-culture model demonstrated that $\mathrm{GH}$ elevated absolute number of double-negative $\left(\mathrm{CD} 4^{-} \mathrm{CD} 8^{-}\right)$and single-positive $\mathrm{CD}^{+}$and $\mathrm{CD} 8^{+}$thymocytes. A decrease in cell number was noted in double-positive $\left(\mathrm{CD} 4^{+} \mathrm{CD} 8^{+}\right)$thymocytes.
\end{abstract}

Conclusions: The results of this study demonstrate that $\mathrm{GH}$ is capable of enhancing the migratory capacity of human thymocytes in the presence of laminin and promotes modulation of thymocyte subsets after co-culture with TEC.

Keywords: Thymocyte, Growth hormone, Laminin, Thymic epithelial cells

\section{Background}

Leukocytes differentiate from multipotent cells in the bone marrow known as hematopoietic stem cells (HSCs). $\mathrm{T}$ cells fully maturate in thymus gland, a primary lymphoid organ that is involved in the differentiation of these cells [1]. The organization of thymic stroma provides specialized niches that ensure appropriate development of $\mathrm{T}$ cell progenitors [2]. This microenvironment comprises distinct cell types, including thymic epithelial cells (TEC), dendritic cells, macrophages and fibroblasts. Moreover, such tridimensional cellular organization is intermingled with an extracellular matrix (ECM)-containing network [3].

Progenitor cells enter the thymus through blood vessels at the cortico-medullary junction and migrate across different thymic regions, from the subcapsular cortex to

${ }^{*}$ Correspondence: smaniotto@icbs.ufal.br

Laboratory of Cell Biology, Institute of Biological Sciences and Health,

Federal University of Alagoas, Maceió, Alagoas, Brazil deep cortex, toward the medulla, where they differentiate [4]. During this migration, thymocytes interact with stromal cells, especially with TEC through cytoplasmic projections and membrane receptors [2]. Thymocyte maturation is based on a series of intracellular signaling events that regulate differentiation, proliferation and cell survival [3]. This process may be monitored through the presence or absence of cell surface markers such as CD4 and CD8 glycoproteins. The most immature thymocytes do not express CD4 or CD8 and are called double-negative cells (DN). Following their development, DN cells express both CD4 and CD8 to become double-positive cells (DP). Finally, upon maturation the cells differentiate into single-positive (SP) thymocytes expressing either $\mathrm{CD} 4$ or $\mathrm{CD} 8$ when they emigrate from the thymus and populate the peripheral lymphoid organs [5-7].

It is well established that immune cells secrete and/or possess receptors for various hormones, indicating bidirectional communication between the neuroendocrine 
and immune systems [8]. Growth hormone (GH) is one of the first known pituitary peptides that have profound effects on regulation of the immune system in vivo through endocrine, paracrine and autocrine mechanisms, along with some cytokines [9].

Numerous thymic functions are modulated by $\mathrm{GH}$. For example, GH acts on thymocytes, increasing proliferation of these cells and stimulates TEC growth, which are essential for $\mathrm{T}$ cell differentiation. Furthermore, GH increases the production of extracellular matrix molecules by TEC and secretion of soluble peptides, such as cytokines and chemokines, directly involved in intrathymic migration of thymocytes and their export to the periphery [10-12].

In the last years, effects of $\mathrm{GH}$ on thymic cells have been studied, however many points need to be clarified. In this study, we investigated the in vitro role of $\mathrm{GH}$ on adhesive and migratory capacities of human thymocytes. Furthermore, laminin production and VLA-6 integrin expression were assessed on TEC after GH-treatment. Finally, thymocyte subsets were examined after contact with TEC (co-culture) in the presence of GH.

\section{Results}

\section{GH enhances thymocyte adhesion on substrates}

In the context of thymocyte differentiation inside thymus gland, these cells interact directly with ECM, receiving signals to maturation. Thus, thymocytes adhere to these molecules, utilizing membrane receptors, and this adhesion is induced or impaired for various hormones [13].

To examine whether thymocyte adhesion on ECMcomposed substrata was modified by GH treatment, these cells were allowed to adhere for $1 \mathrm{~h}$ in Petri dishes coated with laminin or BSA. It was observed that on BSA substrate, GH increases number of adhered thymocytes. On laminin substrate, number of adhered cells was greater than that on BSA substrate, and GH was able to further stimulate thymocyte adhesion on laminin (Fig. 1a). When investigating expression of VLA-6, a laminin receptor, on adhering cells, it was found that adhered thymocytes in the presence of GH had same expression levels of this integrin as adhered cells in the absence of GH (Fig. 1b).

\section{Thymocyte migration through laminin is improved by $\mathrm{GH}$} Cell migration is a multistep process involving changes in the cytoskeleton, cell-substrate adhesions and ECM [14]. Once that GH promotes thymocyte adhesion, mainly on laminin, it was evaluated whether GH modulates thymocyte migration on transwell inserts. After cell migration for $3 \mathrm{~h}$, it was found that GH maintains thymocyte migration at normal rates. However, on laminin coating, the number of migrating cells in $\mathrm{GH}$-treated group was higher than the control (Fig. 2a). Nevertheless, it was observed that expression of VLA-6, in both situations, was unchanged (Fig. 2b).

\section{Increased production of laminin by GH-treated TEC}

Next assessments were focused on human TEC and its laminin production after $\mathrm{GH}$ treating, since they are major cell type of the thymus and the main source of ECM molecules [13]. Thus, an immunocytochemistry assay was performed. Qualitative analysis showed that GH treatment increased laminin production (Fig. 3a). This was confirmed, quantitatively, by fluorescence intensity, which demonstrated a significant increase in laminin accumulation (Fig. 3b).

Considering the differences observed in laminin production patterns, the membrane expression of the laminin receptor was evaluated in TEC after exposure to GH. The expression of VLA- 6 on TEC was essentially the same in control versus GH-treated groups (Fig. 3c).

\section{$\mathrm{GH}$ promotes modulation in thymocyte subsets after co-culture with TEC}

ECM proteins, such as laminin, have been shown to actively contribute to the interaction of developing $\mathrm{T}$ cells with the thymic epithelium during the intrathymic migration of thymocytes. Moreover, thymocyte/TEC interaction is also a two-way process in which the functioning of TEC is dependent on the influence of thymocytes [15]. For this propose, human thymocyte subsets after contact with TEC were evaluated in a co-culture model in vitro, and the contribution of GH to the modulation of thymocyte subsets was examined. Fresh thymocytes were added on the TEC monolayer, with or without $\mathrm{GH}$, and analyzed after $24 \mathrm{~h}$ to determine the absolute numbers of all thymocyte subsets.

Dotplots were first obtained to demonstrate the total number of thymocytes and the percentage of cells in each thymocyte subset (double-negative, double-positive, $\mathrm{CD}^{+}$single-positive and $\mathrm{CD} 8^{+}$single-positive), as shown in Fig. 4a. Absolute cell numbers were then compared between the control and GH-treated groups. The numbers of double-negative $\left(\mathrm{CD} 4^{-} \mathrm{CD} 8^{-}\right)$thymocytes were increased after contact with TEC in the presence of $\mathrm{GH}$. This effect also was observed in the mature subsets, $\mathrm{CD}^{+}{ }^{+}$single-positive and $\mathrm{CD}^{+}$single-positive thymocytes. Interestingly, double-positive $\left(\mathrm{CD} 4^{+} \mathrm{CD} 8^{+}\right)$thymocytes showed reduced cell numbers in the GH-treated group (Fig. 4b).

\section{Discussion}

The thymus is an organ for $\mathrm{T}$ cell differentiation and selection. Developing thymocytes migrate across the thymus to undergo positive and negative selection in 


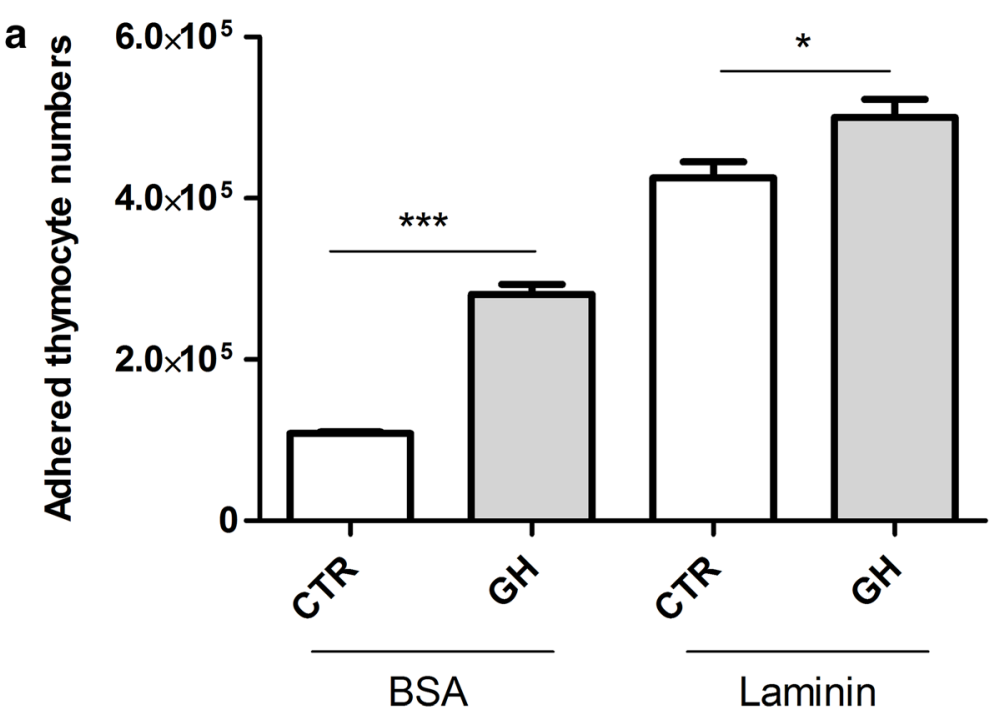

b Control

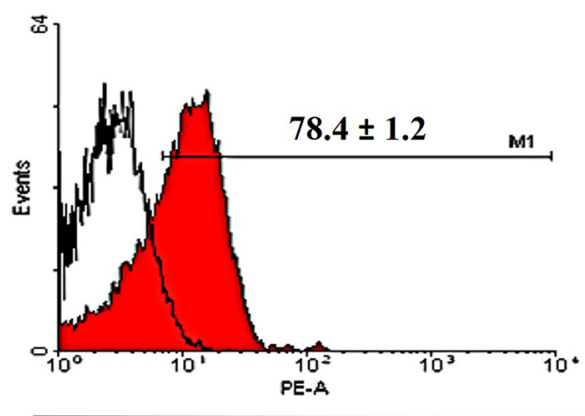

GH

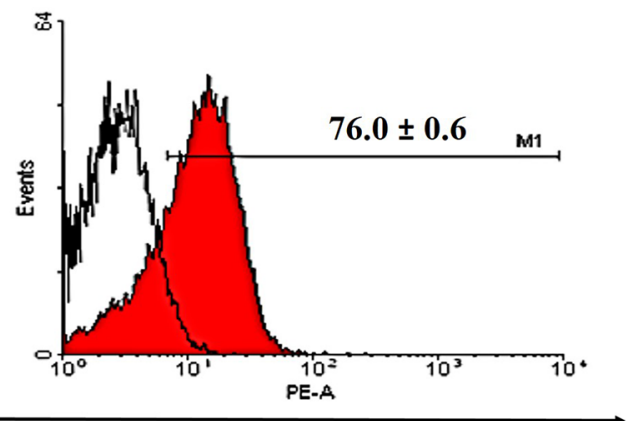

VLA-6

Fig. $1 \mathrm{GH}$ promotes thymocyte adhesion to laminin. Thymocytes were exposed to $\mathrm{GH}(100 \mathrm{ng} / \mathrm{mL})$ for $1 \mathrm{~h}$ and were then allowed to adhere on BSA or laminin substrata. a Absolute number of adhered cells, revealing that GH increases the number of adhered thymocytes on BSA and laminin substrata ( $n=6$ /group). b Representative histograms demonstrate VLA-6 expression on thymocytes after $1 \mathrm{~h}$ of adhesion ( $n=6 / g$ roup). Filled curves represent cells positive for VLA and white curve represents the lg isotype control. Values are expressed as mean \pm SEM. * $\mathrm{*} \leq 0.05$ and ${ }^{* * *} p<0.001$

the cortex and medulla, respectively. In these migration process, several events occur which thymocytes adhere to their surrounding ECM and various types of stromal cells within the thymus. These stromal cells produce ECM, including laminin, which mediates cell-cell contact [16]. Laminin is a heterotrimer of alpha, beta and gamma chains. Combinations of five $\alpha$-, four $\beta$ - and three $\gamma$-chains give rise to at least 16 different laminin isoforms in mammals. Laminin isoforms can drive numerous processes in cells, including cell adhesion, differentiation, proliferation, survival/apoptosis and migration. All these biological processes require the participation of integrins, which are the major receptors for ECM proteins [17]. In addition to these intrinsic factors, it is known that the thymus is a target of neuroendocrine control through the expression of many types of receptors for hormones and neuropeptides, which act in endocrine, paracrine and autocrine manners. In this aspect, $\mathrm{GH}$ exerts pleiotropic actions on the thymic microenvironment [18].

In this study, it was demonstrated that some activities of human thymocytes and TEC are modulated by $\mathrm{GH}$. These findings are consistent with previous studies obtained in murine models from other groups and of our group [19-21]. To promote its effects on thymic cells, the molecule binds to GH receptor present on TEC and thymocyte surface [22]. It was found that GH stimulates human thymocytes to adhere on BSA substrate and also on laminin, in which this adhesive capacity is even more 


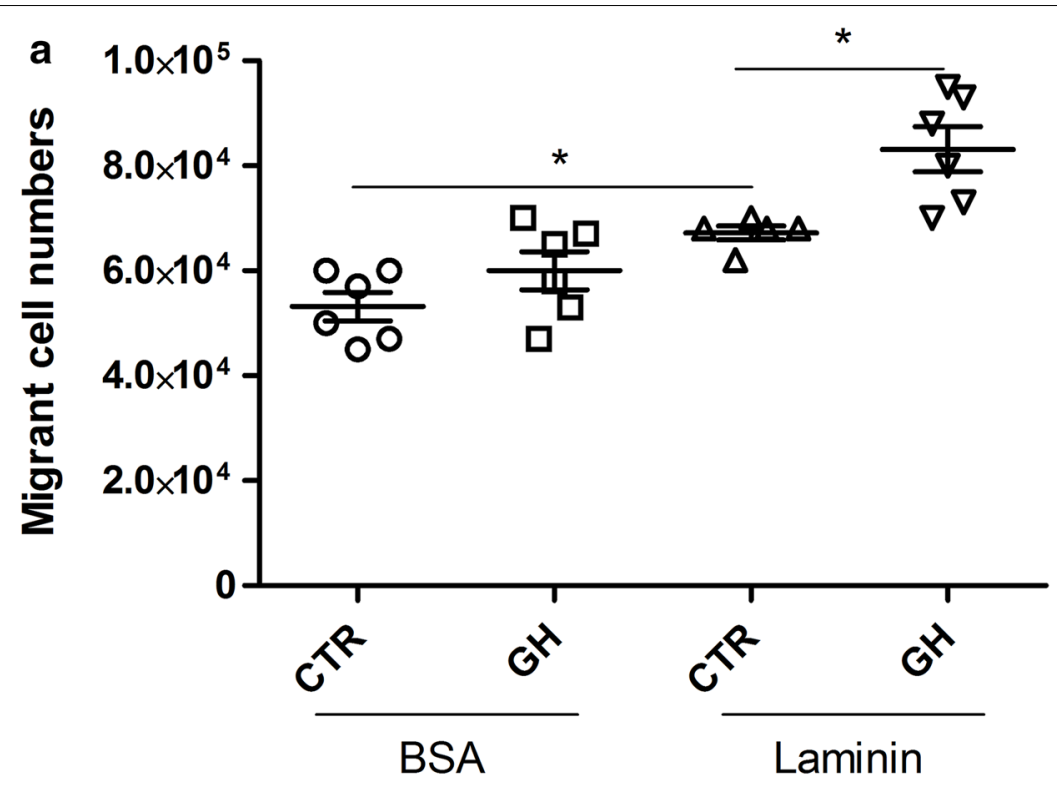

b

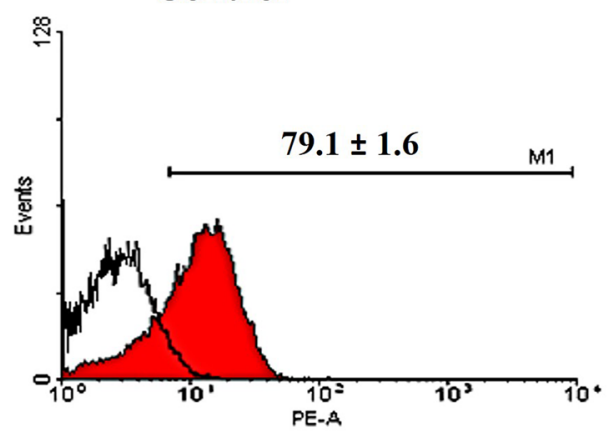

GH

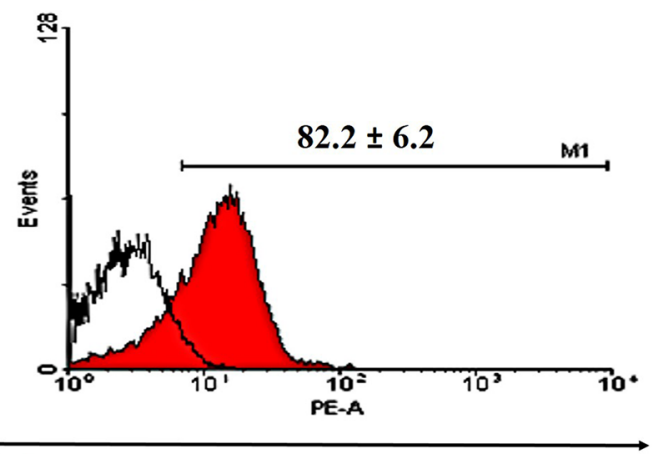

VLA-6

Fig. $2 \mathrm{GH}$ improves thymocyte migration through laminin-coating. After $3 \mathrm{~h}$ of migration in BSA or laminin-coated transwell. a Absolute number of migrant cells, indicating that $\mathrm{GH}$ increases thymocyte migration on laminin substrate. b Representative histograms demonstrate VLA-6 expression on thymocytes after migration. Filled curves represent VLA positive cells and white curve represents Ig the isotype control. Values are expressed as mean \pm SEM, $n=6{ }^{*} p \leq 0.05$

pronounced. These events did not change VLA- 6 expression on adhered thymocytes. It has been described [12] that thymocytes obtained from GH-Tg and GH-injected $\mathrm{BALB} / \mathrm{c}$ mice adhere in higher numbers onto laminin than thymocytes from wild-type mice. Nevertheless, membrane levels of laminin receptor VLA-6 on thymocytes did not change. Thus, our results extend actions of $\mathrm{GH}$, with respect to the adherence of human thymocytes to laminin substrate, and demonstrate that the presence of this hormone also stimulates cell adhesion to a generic substrate (BSA).

Regarding the unchanged VLA-6 expression, Vielkind et al. [23] conceptualize that integrins have low activity in resting cells but can be stimulated to mediate adhesion in response to chemokines and cytokines. These stimuli induce a process of "inside-out" signaling that is typically associated with increased avidity of the integrin by its ligand (as the result of clustering of receptors and their greater lateral mobility) and increases its affinity. Our results demonstrate that exposure of thymocytes to GH does not alter expression of VLA- 6 integrin on the plasma membrane. However, as referenced above, it is not enough to check the number of receptors on cell surface, but is necessary to analyze activation state and avidity of these molecules. Since cells with high numbers of receptors can have them in the resting state, even a small number of active receptors on the membrane can generate evident cellular responses. 


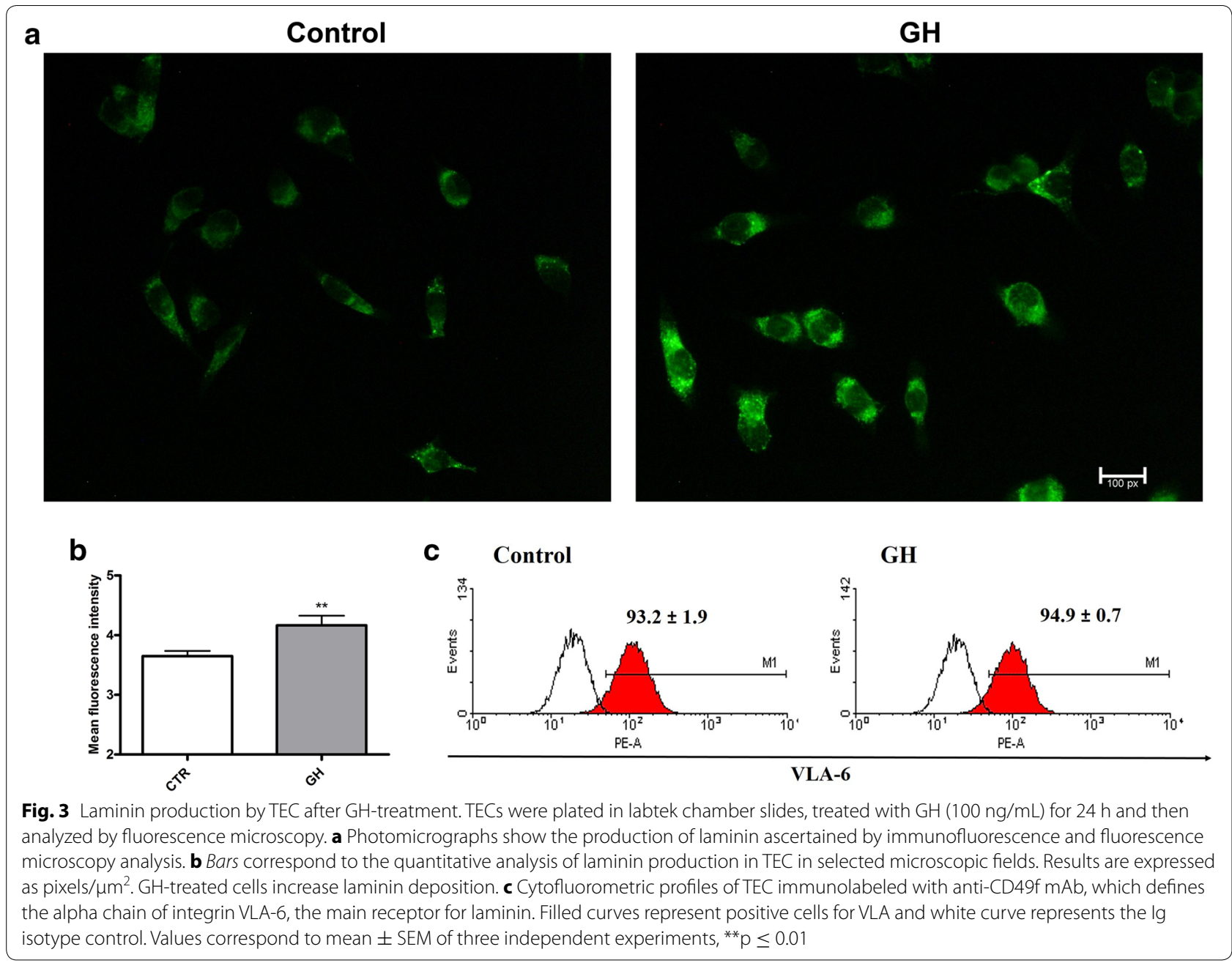

Cell migration is a complex process that involves many variables. For instance, egress of single-positive cells from thymus to periphery requires that cells must be responsive to signals from blood and secondary lymphoid organs. To respond to these stimuli, varied gene expression of chemokine receptors, adhesion molecules, cell signaling molecules and cytoskeletal reorganization is necessary. Therefore, a number of changes are essential for cell migration [24]. GH has been previously implicated in migration of several types of immune cells, including human monocytes [25] and resting or activated human T cells [26]. Furthermore, GH has ability to serve as a chemotactic signal for macrophages and stimulate their migration in vitro [27].

In this study, GH positively modulated human thymocyte migration on laminin substrate, but not on BSA substrate. It raises the notion that the general effect of $\mathrm{GH}$ on thymocyte migration results, at least, from a combined action of ECM in addition to chemokines and other soluble factors in thymus. In murine thymocyte transmigration, $\mathrm{GH}$ only increases the number of migrating cells when combined with CXCL12 chemokine, but no alteration in thymocyte migration is observed after GH treatment individually, suggesting that this hormone enhances sensitivity of these cells to migratory stimuli, as well on substrata (in this case, laminin) that are needed for cell migration [28]. The fact that cell migration is stimulated further when GH is combined with laminin is consistent with the observations of Yanagawa et al. [29], who demonstrate that chemotactic activity of stromal cell-derived factor- $1 \alpha$ (SDF- $1 \alpha)$ is considerably and selectively enhanced in the presence of laminin.

Thymic microenvironment is composed mainly by epithelial cells, which form a meshwork to provide mechanical support and stimuli for proliferation and development of thymocytes. Moreover, macrophages, dendritic cells, fibroblasts and extracellular matrix constitute this network $[13,30]$. TEC produces soluble thymocyte modulators including thymic hormones and cytokines. Additionally, TEC/thymocyte interactions occur through classical 
a

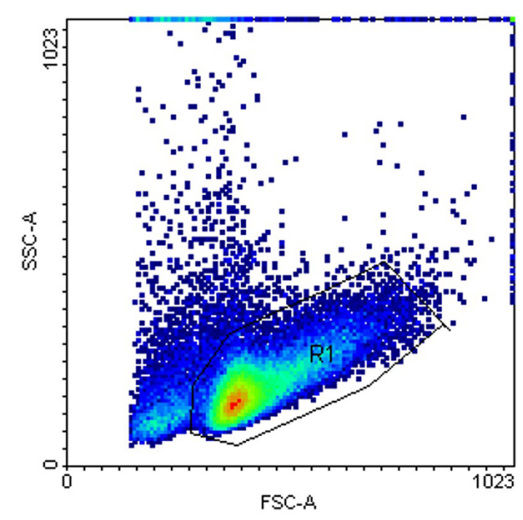

b

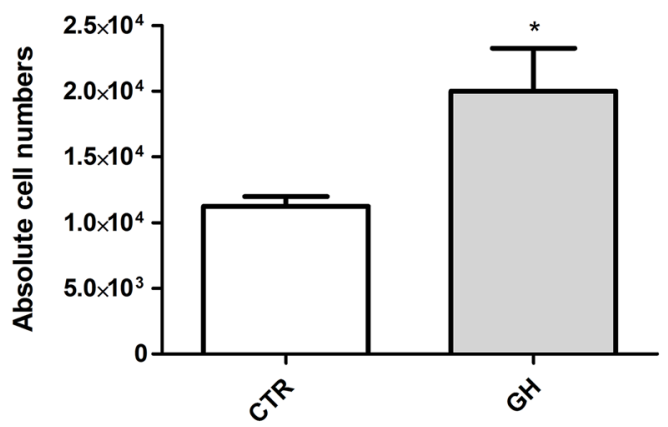

$\mathrm{CD}^{+} \mathrm{SP}$

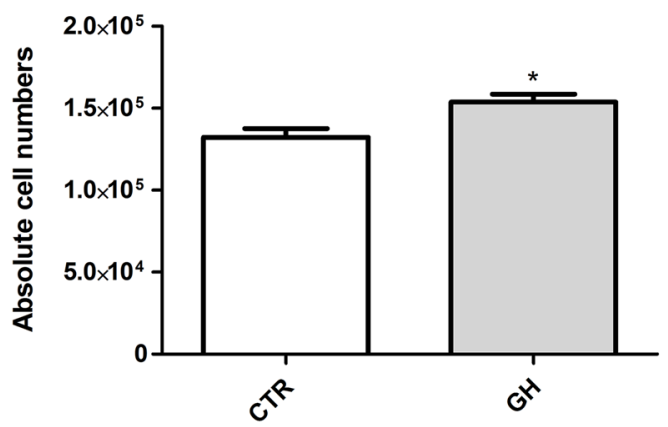

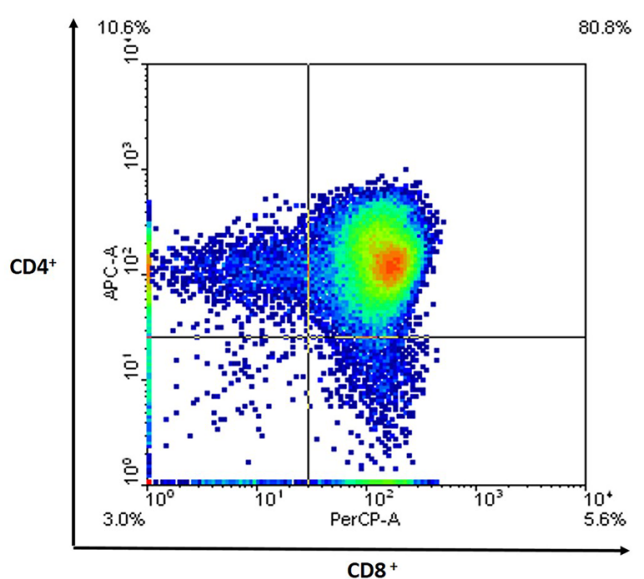

$\mathrm{CD4}^{+} \mathrm{CD}^{+}$
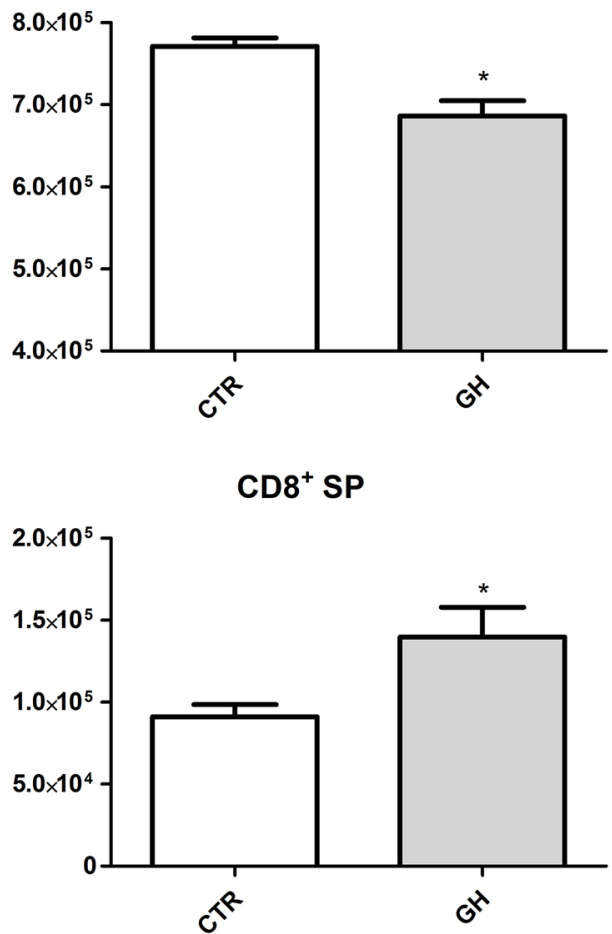

Fig. 4 Modulation of thymocyte subsets by GH-treatment and after contact with TEC. At the end of $24 \mathrm{~h}$ of contact with TEC in the presence or absence of $\mathrm{GH}$, thymocytes were recovered and stained with CD4/CD8 mAbs, fixed, and analyzed by flow cytometry. In a viable thymocytes were selected and quadrants were used to individualize subsets, showing the cell percentage in each. In $\mathbf{b}$ bars show the absolute numbers of CD4/ CD8-defined thymocyte subsets. GH induced distinct modulation in subsets, increasing $C D 4^{-} \mathrm{CD} 8^{-}, \mathrm{CD} 4^{+}$and $\mathrm{CD} 8^{+}$subsets, and decreasing the $C D 4^{+} C D 8^{+}$subset. Results are expressed as mean $\pm \operatorname{SEM}(n=6 /$ group $) .{ }^{*} p \leq 0.05$ and ${ }^{* *} p \leq 0.01$

adhesion molecules. TEC can bind and interact with maturing thymocytes by extracellular matrix ligands and respective receptors. Laminin is distributed heterogeneously within thymic parenchyma, being produced by TECs [13]. Our results showed augmented production of laminin by TEC after GH-treatment. This finding corroborates the idea that this network of epithelial cells is controlled by extrinsic circuits such as neuroendocrine axis. For instance, the augmentation of ECM expression as seen, not only in cultures of TEC lines, but also in primary cultures of epithelial cells derived from isolated thymic nurse lymphoepithelial complexes [11], and in mice overexpressing $\mathrm{GH}(\mathrm{GH}-\mathrm{Tg})$ that exhibit enhanced laminin deposition in cortical and medullary regions of thymic lobules [12]. 
Considering these effects of GH on human thymocytes and TEC separately, we observed its effects on TEC/thymocyte co-culture. In this assay, we demonstrated two main aspects. First, as shown by immunocytochemistry, GH stimulates laminin production by TEC, and this phenomenon is directly related to thymocyte adhesion and migration, as shown by our initial results. Thus, GH contributes to intrathymic differentiation that occurs concomitantly with thymocyte adhesion and migration through thymic stroma [18]. The second observation is fluctuation in subsets, which is displayed after $24 \mathrm{~h}$ of contact with TEC, in the presence of GH.

We hypothesize that GH may act indirectly promoting secretion of interleukin-7 (IL-7) by TEC. GH may act directly upon immune tissues or its effects may be mediated indirectly through insulin-like growth factor-1 (IGF-1) $[8,9]$. Reduced serum concentration of IL-7, smaller thymic volume and diminished output of naive T-lymphocytes observed in GH deficiency children suggest that thymic function may be impaired in the presence of defective $\mathrm{GH}$ production. In these children, $\mathrm{GH}$ deficiency was associated with a pattern of impaired synchronous release of GH and IGF-1 [31]. Furthermore, GH treatment enhances circulating levels of IGF-1 and IL-7 of HIV-1-infected adults. These findings suggest that IGF-1 occupies an important role in GH-mediated enhancement of $\mathrm{T}$ cell production and offer fundamental insight into the mechanism of GH effects on the human immune system [32]. More recently, IGF-1, a proximal mediator of the metabolic action of $\mathrm{GH}$, was found to induce expression and release of IL-7 in cultured human thymic epithelial cells [33].

The role of IL-7 in thymopoiesis is multifaceted, promoting thymocyte proliferation and survival by upregulating anti-apoptotic protein $\mathrm{Bcl}-2$ and downregulating pro-apoptotic protein Bax [34]. GH can modulate genes committed to distinct biological activities of thymic epithelial cells, including expression of this cytokine [35].

IL-7 receptor is expressed on DN thymocytes but is downregulated in DP thymocytes and is restored after positive selection, when thymocytes complete differentiation process (SP thymocytes) [36]. DN and both SP subsets thymocytes were responsive to IL-7 and DP population responded poorly [37]. If TEC increases IL-7 secretion because of GH treatment, these thymocyte subsets (DN, CD4 ${ }^{+} \mathrm{SP}$ and $\mathrm{CD}^{+} \mathrm{SP}$ ) would display increased proliferation, which would explain their higher absolute number, whereas the numbers of DP thymocytes decreases in comparison to control group.

Considering all these data, we suggest that GH has pleiotropic effects on lymphoid (thymocytes) and non-lymphoid (TEC) compartments of thymus, thus corroborating with physiology of this organ in supplying $\mathrm{T}$ cells to the organism. This study also contributes to current information about effects of $\mathrm{GH}$ on human thymic cells, which is important when proposing GHbased therapies for the recovery of the immune system.

\section{Conclusions}

These results point that GH is involved in adhesive and migratory capacity of human thymocytes and modulates production of laminin by TEC, without altering VLA-6 expression on both cells. Furthermore GH positively increases absolute number of double-negative $\left(\mathrm{CD} 4^{-} \mathrm{CD} 8^{-}\right)$thymocytes and single-positive $\mathrm{CD} 4^{+}$and $\mathrm{CD}^{+}$thymocytes after co-culture with TEC in vitro. In this context, considering that GH has been used as an adjuvant therapeutic agent in immunodeficiencies, these data presented herein provide background knowledge for future GH-based immunotherapy interventions.

\section{Methods \\ Reagents and antibodies}

Recombinant human GH was purchased from Dong-A Pharmaceutical Co., Ltd (Dalseong-Gun, Daegu, South Korea). Laminin 111 protein, primary anti-laminin antibody and secondary goat anti-rabbit-FITC conjugated antibody were purchased from Sigma-Aldrich (St. Louis, MO, USA). Monoclonal antibodies: anti-CD4 allophycocyanin (APC), anti-CD8 peridinin chlorophyll protein (PerCP), anti-CD49f phycoerythrin (PE) and rat IgG2a $\mathrm{PE}$ were purchased from eBioscience (San Diego, CA, USA). Fetal bovine serum (FBS), RPMI-1640 medium, L-glutamine, gentamicin, Trypsin-EDTA, phosphate buffered saline (PBS) and bovine serum albumin (BSA) were obtained from Sigma-Aldrich.

\section{Cells and culture conditions}

Human thymic fragments were obtained from children (aged 1 day to 9 years) undergoing corrective cardiac surgery at Santa Casa de Misericórdia Hospital. Tissue was minced, large aggregates were removed by passing through a nylon mesh and thymocytes in suspension were kept in RPMI-1640 supplemented with $10 \%$ heatinactivated FBS, $1 \%$ L-glutamine and $40 \mathrm{mg} / \mathrm{mL}$ gentamicin, at $4{ }^{\circ} \mathrm{C}$ before the experiments. All procedures were approved by the ethics committee on research of UFAL by protocol number 028370/2010-07.

Human thymic epithelial cell line (TEC), generated from explants of a postnatal organ [38], was utilized in this study. Cell cultures were grown in a complete RPMI1640 medium, at $37{ }^{\circ} \mathrm{C}$ in a humidified $5 \% \mathrm{CO}_{2}$ atmosphere. Passage of cells by trypsin-EDTA treatment was performed after every 3-4 days. 


\section{Thymocyte adhesion assay}

To assess thymocyte adhesive capacity, 6-well culture plates were coated for $1 \mathrm{~h}$ at room temperature with $10 \mu \mathrm{g} / \mathrm{mL}$ laminin or BSA as a control. In these assays, $1 \times 10^{7}$ fresh thymocytes were allowed to adhere on substrata for $1 \mathrm{~h}$, in the presence or absence of GH (100 ng/ $\mathrm{mL}$ ) and $3 \mathrm{~mL} \mathrm{RPMI/FBS} 2 \%$, at $37^{\circ} \mathrm{C}$. After removal of non-adherent thymocytes by PBS washing, adherent thymocytes were harvested with cool PBS, counted and analyzed by flow cytometry.

\section{Thymocyte migration assay}

Thymocyte migratory activity was evaluated using a transwell system $(6.5-\mathrm{mm}$ diameter, $5-\mu \mathrm{m}$ pore size, polycarbonate membrane) (Corning Costar, Cambridge, MA, USA) using cell suspensions. In this chemotaxis assay, membranes were coated on both sides with $10 \mu \mathrm{g} / \mathrm{mL}$ laminin or BSA for $1 \mathrm{~h}$ at $37^{\circ} \mathrm{C}$, followed by $1 \mathrm{~h}$ of blocking with $1 \%$ BSA. Thymocytes $\left(2.5 \times 10^{6}\right)$ in $100 \mu \mathrm{L} 0.5 \%$ BSA/RPMI 1640 with or without GH $(100 \mathrm{ng} / \mathrm{mL})$ were then added to the upper chamber, and $600 \mu \mathrm{L} 0.5 \% \mathrm{BSA} / \mathrm{RPMI} 1640$ was added to the lower chamber. After $3 \mathrm{~h}$ of incubation at $37{ }^{\circ} \mathrm{C}$ in $5 \%$ $\mathrm{CO}_{2}$-containing air, cells migrated into the lower chambers and were removed, counted and analyzed by flow cytometry.

\section{Cytofluorometry}

Thymocyte suspensions in PBS with $4 \%$ FBS were incubated with a mixture of appropriate dilutions of the following mAb: anti-CD4/APC, anti-CD8/PerCP, anti$\mathrm{CD} 49 \mathrm{f} / \mathrm{PE}$, as well as, isotype-matched negative controls for each fluorochrome. Cells were stained for $20 \mathrm{~min}$ at $4{ }^{\circ} \mathrm{C}$, fixed with $\mathrm{PBS} /$ Formaldehyde $2 \%$ and analyzed by flow cytometry on FACSCanto II (BD Biosciences). A gate excluding cell debris and nonviable cells was applied using forward versus side scatter parameters pre-established for thymocytes. Analysis with FACSDiva software (BD Biosciences) was performed after recording 10,00050,000 events for each sample.

TEC were grown in 6-well plate $\left(3 \times 10^{5}\right.$ cells/well $)$ and treated with $\mathrm{GH}(100 \mathrm{ng} / \mathrm{mL})$ for $24 \mathrm{~h}$, in $500 \mu \mathrm{L}$ RPMI/FBS $2 \%$. Cells were recovered by scraping and incubated with diluted antibody (anti-CD49f) or isotype-matched negative control. After washing, the cells were fixed with PBS/Formaldehyde $2 \%$ and analyzed by flow cytometry.

\section{Immunocytochemistry}

Human TEC $\left(5 \times 10^{3}\right)$ were plated in a 8 -well Lab-tek chamber slides, with complete medium for $16 \mathrm{~h}$ to allow cell adhesion. The medium was then replaced and cells were treated with $\mathrm{GH}(100 \mathrm{ng} / \mathrm{mL})$. After $24 \mathrm{~h}$, cultures were washed with PBS and fixed with methanol, followed by incubation with anti-laminin primary antibody for $1 \mathrm{~h}$ at room temperature, washed with PBS, and incubated with goat anti-rabbit-FITC conjugated secondary antibody for $45 \mathrm{~min}$ at room temperature. Immunostained samples were analyzed by fluorescence microscopy (Nikon Eclipse 50i; Nikon Instruments Inc., Chicago, IL, USA). A negative control with secondary antibody was used and did not show any significant immunolabeling. Quantitative fluorescence analysis were performed by transforming specific staining to pixels and by dividing the total pixel numbers by the area analyzed, thus obtaining the number of pixels $/ \mu \mathrm{m}^{2}$, using the ImageJ software.

\section{TEC/thymocyte co-culture assay}

Co-culture assays were performed in 24-well plates at a ratio of 100 thymocytes/TEC. Firstly, $1 \times 10^{4}$ TEC were plated in a well with $500 \mu \mathrm{L}$ complete RPMI and after $16 \mathrm{~h}$ of cell adhesion, $1 \times 10^{6}$ fresh thymocytes were plated on the TEC monolayer while replacing the medium with $500 \mu \mathrm{L}$ RPMI/FBS $2 \%$ with or without GH. After $24 \mathrm{~h}$ of co-culture, thymocytes were recovered, counted and analyzed by flow cytometry.

\section{Statistical analysis}

The data obtained were analyzed using one-way ANOVA followed by Newman-Keuls post-test or by Student's $\mathrm{t}$ test and considered as statistically significant when $p$ values were $\leq 0.05$. Values were presented as the mean \pm standard error of the mean (SEM).

\section{Authors' contributions}

MPL and LFAV were responsible for conducting the experiments, data acquisition and analysis. AAMR provided human thymic fragments. SS conceived the study and supervised the research project. All authors read and approved the final manuscript.

\section{Acknowledgements}

This study was financially supported by CNPq and FAPEAL. Authors thank the technician of Laboratory of Cell Biology, Luis Alex de Carvalho Wanderley, for assistance in data acquisition on the cytometer.

\section{Competing interests}

The authors declare that they have no competing interests.

Received: 22 December 2015 Accepted: 12 August 2016

Published online: 02 September 2016

\section{References}

1. Petrie HT, Zúñiga-Pflücker JC. Zoned out: functional mapping of stromal signaling microenvironments in the thymus. Annu Rev Immunol. 2007;25:649-79.

2. Griffith AV, Fallahi M, Nakase H, Gosink M, Young B, Petrie HT. Spatial mapping of thymic stromal microenvironments reveals unique features influencing T lymphoid differentiation. Immunity. 2009;31:999-1009. 
3. Savino W, Mendes-Da-Cruz DA, Smaniotto S, Silva-Monteiro E, VillaVerde DM. Molecular mechanisms governing thymocyte migration: combined role of chemokines and extracellular matrix. J Leukoc Biol. 2004;75:951-61.

4. Porritt HE, Gordon K, Petrie HT. Kinetics of steady-state differentiation and mapping of intrathymic-signaling environments by stem cell transplantation in nonirradiated mice. J Exp Med. 2003;198:957-62.

5. Halkias J, Melichar HJ, Taylor KT, Robey EA. Tracking migration during human T cell development. Cell Mol Life Sci. 2014;71:3101-17.

6. Swat W, Montgrain V, Doggtt TA, Douangpanya J, Puri K, Vermi W, Diacovo TG. The essential role of PI3K $\delta$ and PI3K $\gamma$ in thymocyte survival. Blood. 2006;107:2415-22.

7. Ciofani M, Zuniga-Pflucker JC. The thymus as an inductive site for T lymphopoiesis. Annu Rev Cell Dev Biol. 2007;23:463-93.

8. Savino W, Mendes-da-Cruz DA, Lepletier A, Dardenne M. Hormonal control of T-cell development in health and disease. Nat Rev Endocrinol. 2016;12:77-89.

9. Savino W, Dardenne M. Neuroendocrine control of the thymus. Endocr Rev. 2000;21:412-43.

10. Savino W. Neuroendocrine control of T cell development in mammals: role of growth hormone in modulating thymocyte migration. Exp Physiol. 2007;92:813-7.

11. de Mello-Coelho V, Villa-Verde DM, Dardenne M, Savino W. Pituitary hormones modulate cell-cell interactions between thymocytes and thymic epithelial cells. J Neuroimmunol. 1997;76:39-49.

12. Smaniotto S, Mello-Coelho V, Villa-Verde DM, Pléau JM, Postel-Vinay MC, Dardenne M, Savino W. Growth hormone modulates thymocyte development in vivo through a combined action of laminin and CXCL12. Endocrinology. 2005;146:3005-17.

13. Gameiro J, Nagib P, Verinaud L. The thymus microenvironment in regulating thymocyte differentiation. Cell Adh Migr. 2010;4:382-90.

14. Ridley AJ. Rho GTPases and cell migration. J Cell Sci. 2001;114:2713-22.

15. Farias-de-Oliveira DA, Cotta-de-Almeida V, Villa-Verde DM, Riederer I, Meis JD, Savino W. Fibronectin modulates thymocyte-thymic epithelial cell interactions following Trypanosoma cruzi infection. Mem Inst Oswaldo Cruz. 2013;108:825-31.

16. Ayres-Martins S, Lannes-Vieira J, Farias-De-Oliveira DA, Brito JM, VillaVerde DMS, Savino W. Phagocytic cells of the thymic reticulum interact with thymocytes via extracellullar matrix ligands and receptors. Cell Immunol. 2004:229:21-30.

17. Golbert DC, Santana-van-Vliet E, Mundstein AS, Calfo V, Savino W, de Vasconcelos AT. Laminin-database v. 2.0: an update on laminins in health and neuromuscular disorders. Nucleic Acids Res. 2014;42:D426-9.

18. Savino W, Dardenne M. Pleiotropic modulation of thymic functions by growth hormone: from physiology to therapy. Curr Opin Pharmacol. 2010;10:434-42.

19. Barnard A, Layton D, Hince M, Sakkal S, Bernard C, Chidgey A, Boyd R. Impact of the neuroendocrine system on thymus and bone marrow function. Neuroimmunomodulation. 2008;15:7-18.

20. Kermani H, Goffinet L, Mottet M, Bodart G, Morrhaye G, Dardenne O, Renard C, Overbergh L, Baron F, Beguin Y, Geenen V, Martens HJ. Expression of the growth hormone/insulin-like growth factor axis during balb/c thymus ontogeny and effects of growth hormone upon ex vivo T cell differentiation. Neuroimmunomodulation. 2012;19:137-47.

21. Smaniotto S, Mendes-da-Cruz DA, Carvalho-Pinto CE, Araujo LM, Dardenne M, Savino W. Combined role of extracellular matrix and chemokines on peripheral lymphocyte migration in growth hormone transgenic mice. Brain Behav Immun. 2010;24:451-61.

22. Savino W, Postel-Vinay MC, Smaniotto S, Dardenne M. The thymus gland: a target organ for growth hormone. Scand J Immunol. 2002;55:442-52.
23. Vielkind S, Gallagher-Gambarelli M, Gomez M, Hinton HJ, Cantrell DA. Integrin regulation by RhoA in thymocytes. J Immunol. 2005;175:350-7.

24. $\mathrm{Xu} X, \mathrm{Ge} \mathrm{Q}$. Maturation and migration of murine CD4 single-positive thymocytes and thymic emigrants. Comput Struct Biotechnol J. 2014;9:e201403003.

25. Wiedermann CJ, Reinisch N, Braunsteiner H. Stimulation of monocyte chemotaxis by human growth hormone and its deactivation by somatostatin. Blood. 1993;82:954-60.

26. Taub DD, Tsarfaty G, Lloyd AR, Durum SK, Longo DL, Murphy WJ. Growth hormone promotes human T cell adhesion and migration to both human and murine matrix proteins in vitro and directly promotes xenogeneic engraftment. J Clin Invest. 1994;94:293-300.

27. Su HW, Lanning NJ, Morris DL, Argetsinger LS, Lumeng CN, Carter-Su C. Phosphorylation of the adaptor protein $\mathrm{SH} 2 \mathrm{~B} 1 \beta$ regulates its ability to enhance growth hormone-dependent macrophage motility. J Cell Sci. 2013:126:1733-43.

28. Smaniotto S, Martins-Neto AA, Dardenne M, Savino W. Growth hormone is a modulator of lymphocyte migration. Neuroimmunomodulation. 2011;18:309-13.

29. Yanagawa $Y$, Iwabuchi K, Onoe K. Enhancement of stromal cell-derived factor-1-induced chemotaxis for CD4/8 double-positive thymocytes by fibronectin and laminin in mice. Immunology. 2001:104:43-9.

30. Chaudhry MS, Velardi E, Dudakov JA, van den Brink MR. Thymus: the next (re)generation. Immunol Rev. 2016;271:56-71.

31. Vigano A, Saresella M, Trabattoni D, Giacomet V, di Natale B, Merlo M, Venuto A, Villa ML, Vanzulli S, Ferrante P, Clerici M. Growth hormone in T-lymphocyte thymic and postthymic development: a study in HIVinfected children. J Pediatr. 2004;145:542-8.

32. Napolitano LA, Schmidt D, Gotway MB, Ameli N, Filbert EL, Ng MM, Clor $J$, Epling L, Sinclair E, Baum PD, Li K, Killian ML, Bacchetti P, McCune JM. Growth hormone enhances thymic function in HIV-1-infected adults. J Clin Invest. 2008;118:1085-98.

33. Bodart G, Goffinet L, Morrhaye G, Farhat K, de Saint-Hubert M, DebacqChainiaux F, Swine C, Geenen V, Martens HJ. Somatotrope GHRH/GH/ IGF-1 axis at the crossroads between immunosenescence and frailty. Ann NY Acad Sci. 2015;1351:61-7.

34. Young CD, Angel JB. HIV infection of thymocytes inhibits IL-7 activity without altering CD127 expression. Retrovirology. 2011;8:72.

35. De Mello-Coelho V, Savino W, Postel-Vinay MC, Dardenne M. Role of prolactin and growth hormone on thymus physiology. Dev Immunol. 1998;6:317-23

36. Tani-ichi S, Shimba A, Wagatsuma K, Miyachi H, Kitano S, Imai K, Hara T, Ikuta K. Interleukin-7 receptor controls development and maturation of late stages of thymocyte subpopulations. Proc Natl Acad Sci USA. 2013;110:612-7.

37. Van De Wiele CJ, Marino JH, Murray BW, Vo SS, Whetsell ME, Teaque TK. Thymocytes between the beta-selection and positive selection checkpoints are nonresponsive to IL-7 as assessed by STAT-5 phosphorylation. J Immunol. 2004;172:4235-44.

38. Fernández E, Vicente A, Zapata A, Brera B, Lozano JJ, Martínez C, Toribio ML. Establishment and characterization of cloned human thymic ephitelial cell lines. Analysis of adhesion molecule expression and cytokine production. Blood. 1994:83:3245-54.

\section{Submit your next manuscript to BioMed Central and we will help you at every step:}

- We accept pre-submission inquiries

- Our selector tool helps you to find the most relevant journal

- We provide round the clock customer support

- Convenient online submission

- Thorough peer review

- Inclusion in PubMed and all major indexing services

- Maximum visibility for your research

Submit your manuscript at www.biomedcentral com/submit 